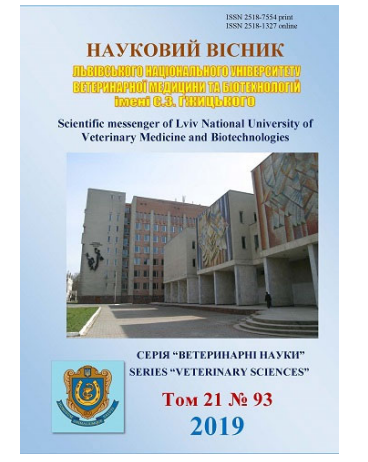

Науковий вісник Дьвівського національного університету ветеринарної медицини та біотехнологій імені С.3. Гжицького.

\author{
Серія: Ветеринарні науки
}

Scientific Messenger of Lviv National University of Veterinary Medicine and Biotechnologies.

Series: Veterinary sciences

UDC 619:615-614.9

\title{
The determination of mineral density indices of the thigh bone by densitometry data in rats, for experimental fumonizinotoxycosis
}

\author{
H.V. Rudyk \\ State Scientific-Research Control Institute of Veterinary Medicinal Products and Feed Additives, Lviv, Ukraine
}

Article info

Received 17.02.2019

Received in revised form 19.03.2019

Accepted 20.03.2019

State Scientific-Research Control Institute of Veterinary Medicinal Products and Feed Additives

11, Donetska str., Lviv,

79019, Ukraine.

Tel.: +38-067-340-45-10

E-mail: galusik.77@gmail.com
Rudyk, H.V. (2019). The determination of mineral density indices of the thigh bone by densitometry data in rats, for experimental fumonizinotoxycosis. Scientific Messenger of Lviv National University of Veterinary Medicine and Biotechnologies. Series: Veterinary sciences, 21(93), 169_ 178. doi: $10.32718 /$ nvlvet 9330

The article deals with the analytical methods that have allowed to provide detailed information on the material content of bones and structural organizations of both inorganic and organic bone components. The information provided in the present search may increase the knowledge of the influence of fumonisins on the structure and bone in general. On the basis of osteometric measurements, the geometry of the transverse section of the middle diaphysis is determined. They included a definition both the external and internal diameters of the transverse section of the middle of the diaphysis (both in the medial-lateral, and in the anterior-posterior area). The geometric properties are calculated: cortical cross-sectional area, average relative thickness of walls and cortical index. In addition, since during the force analysis, the bone was loaded in the anterior-posterior area, the vertical cortical index, the moment of inertia of the cross-section and the radius of rotation around the medial-lateral axis were calculated. According to the results of comprehensive studies, we found that the intoxication of animals with fumonisin did not affect the body weight and the weight of the femoral bones, although in the fumonisin-induced doses of rats there was a decrease in the mechanical and geometric properties of the bones. The values of mineral density of bone tissue did not differ between groups, but in the experimental group of animals that were fumonisin intoxicated, the mineral content of bone and the percentage of bone ash were lower than in the control group. A detailed mineral analysis of bones showed that the content of $\mathrm{Ca}, \mathrm{Cu}, \mathrm{Fe}, \mathrm{Mn}, \mathrm{Sr}$ and $\mathrm{Zn}$ in bones was significantly decreased in fumonisin intoxicated rats compared to the control group of animals. In addition, changes in the structure of the bone and mineral phase (reduction in the size of bone hydroxyapatite crystals) were noted. Seventy percent of the bones consist of inorganic mineral hydroxyapatite, which includes calcium phosphate, calcium carbonate, calcium fluoride, calcium hydroxide and citrate. This inorganic component is preferably crystalline, although it may be in amorphous forms. Replacement mechanisms occurring in bone hydroxyapatite include intercrystalline exchange and recrystallization due to the dissolution and reforming of crystals with the addition of new ions to the crystalline structure, which replace the Ca ${ }^{2+}$ or adsorbed on the surface of the crystals. The mechanisms of replacement that was marked by changes in the group of animals from intoxicated with fumonisin, changes were noted in the structure of the bone and mineral phase, there was a decrease in the size of bone hydroxyapatite crystals.

Key words: mineral density of thigh bone, densitometry, rats of vistar line, thigh bone, fumonisine.

\section{Визначення показників мінеральної щільності стегнової кістки за даними денситометрії у щурів, за експериментального фумонізинотоксикозу}

\author{
Г.В. Рудик
}

Державний науково-дослідний контрольний інститут ветеринарних препаратів та кормових добавок, м. Львів, Україна 
У статті використані аналітичні методи, які дозволили надати детальну інформацію про матеріальний склад кістки та структурні організації як неорганічних, так і органічних компонентів кістки. Інформація, отримана в представленому дослідженні, може розширити знання про вплив фумонізинів на структуру кістки. На основі остеометричних вимірювань визначена геометрія поперечного перерізу середнього діафіза. Вони включали визначення як зовнішнього, так і внутрішнього діаметрів поперечного перерізу середини діафіза (як в медіально-латеральній, так і в передньо-задній площині). Розраховані геометричні властивості: кортикальна площа поперечного перерізу, середня відносна товщина стінок $і$ кортикальний індекс. Крім того, оскільки під час силового аналізу кістка була навантажена в передньо-задній площині, розраховано вертикальний кортикальний індекс, момент інериї поперечного перерізу і радіус обертання навколо медіально-латеральної осі. За результатами комплексних досліджень нами встановлено, що інтоксикачія тварин фумонізином не впливала на вагу тіла і вагу стегнових кісток, хоча в інтоксикованих фумонізином щурів спостерігалося зниження механічних та геометричних властивостей кісток. Значення мінеральної щүільності кісткової тканини не відрізнялися між групами, але у дослідній групі тварин, інтоксикованих фумонізином мінеральний вміст кістки і відсоток кісткової золи були нижчими ніж у контрольній групі. Детальний мінеральний аналіз кісток показав, ццо вміст у кістках $\mathrm{Ca}, \mathrm{Cu}, \mathrm{Fe}, \mathrm{Mn}$, Sr та Zn значно зменшувався у шурів, інтоксикованих фумонізином, у порівнянні із контрольною групою тварин. Також були відмічені зміни у структурі кістково-мінеральної фази (зменшення розміру нанокристалів гідроксиапатиту кістки). Сімдесят відсотків кістки складаються з неорганічного мінерального гідроксиапатиту. Цей неорганічний компонент є переважно кристалічним, хоча може бути в аморфних формах. Механізми заміщення, щзо відбуваються в гідроксиапатиті кістки, включають міжкристалічний обмін і рекристалізацію внаслідок розчинення $і$ риформінгу нанокристалів з додаванням нових іонів до кристалічної структури, щзо замінюють $\mathrm{Ca}^{2+}$ або адсорбуються на поверхні нанокристалів.

Ключові слова: мінеральна щиільність стегнової кістки, денситометрія, щури лінї вістар, стегнова кістка, фумонізини.

\section{Вступ}

Фумонізини токсичні метаболіти грибів роду Fusarium proliferatum та Fusarium verticillioides, які були знайдені не тільки в зернових культурах (включаючи кукурудзу) чи продуктах рослинництва, а й у гранульованих кормах, що може вказувати на те, що вони $є$ стійкими до процесу гранулювання. Серед низки різних груп фумонізинів (FB) (A, B, C і Р) відомі чотири мікотоксини фумонізинів (FB): B1, B2, B3 і B4, однак тільки FB B1 і В2 є токсично небезпечними і через це, а також через значну їхню чисельність (Šegvić \& Pepeljnjak, 2001; Kotsyumbas et al., 2016) є надзвичайно важливими. Хоча FB B1 структурно відрізняється від FB В2 за кількістю і положенням гідроксильних груп, обидва $\epsilon$ інгібіторами синтезу сфінголіпідів. Тому FB беруть участь у регуляції росту клітин, диференціації і навіть трансформації раку (Ross et al., 1992). С багато відомостей з різних країн Африки, Північної та Південної Америки, Азії та Європи щодо рівня FB B1 або FB B2 у зернових культурах, який становить від 0,02 до 25,9 мг/кг і від 0,05 до 11,3 мг/кг відповідно (Placinta et al., 1999) та щодо їх впливу на організм тварин.

С дані, що найбільш вразливі до впливу FB - коні та свині, у яких зафіксовано клінічну проблему (лейкоенцефаломаляцію коней; набряк легень свиней) (EFSA, 2018). Також є літературні дані про ураженість печінки та нирок за впливу FB, що спостерігається у коней, свиней, овець, гризунів та птиці (Riley \& Voss, 2006; Antonissen et al., 2015). Вважається, що птахи досить стійкі до шкідливого впливу FB. Що стосується парнокопитних тварин, то вплив FB на організм неоднозначний. Біодоступність і токсичність FB у жуйних тварин $\epsilon$ слабшою порівняно із моногастричними тваринами. Це означає, що токсичні дози FB або клінічні ознаки токсичності варіюються між різними видами і залежать від шляхів введення, а також від статі або віку (Ledoux et al., 1992). Дослідження, проведені на самцях та самках щурів, показали, що споживання їжі, яка містила в собі FB В1 в межах 1, 9, 27 або 81 мг/кг/добу протягом 13 тижнів не призводило до змін у масі тіла між контрольними та інтоксикованими тваринами. Проте спостерігалася ниркова токсичність, яка виникала після введення FB В1 у дозі 27 мг/кг м.т./добу (Voss et al., 1995). Більш того, у щурів, які отримували в раціон корми, що містили FB B1 в межах 15, 50 і 150 мг/кг протягом 4 тижнів, виявляли гепатотоксичність в обох статей. В інших дослідженнях був встановлений токсичний вплив FB B1 за 0,7, 3,5, 6,8, 15 і 25 мг/кг маси тіла щурів протягом 21 дня (Gelderblom et al., 1996).

Є дані, що дисфункція печінки та нирок призводить до порушень з боку кісткової тканини. Утворення та ріст кісток контролювався складною групою процесів зворотного зв'язку, які залежать від багатьох біологічних та екологічних факторів, таких як вплив токсикантів, зокрема фумонізинів (Hodgson et al., 2008; Álvarez-Lloret et al., 2009; Rodríguez-Estival et al., 2013). Польськими дослідниками проведені токсикологічні дослідження, котрі показали, що кісткова тканина дуже чутлива до багатьох видів токсичних речовин, таких як важкі метали (Кадмій, Свинець) або мікотоксини (Дезоксиніваленол), які впливають на склад, мінералізацію і механічну міцність кісток (Tomaszewska et al., 2016; 2017; 2018). У наших попередніх дослідженнях описаний факт порушення гомеостазу кісток, за впливу FB на організм щурів.

Відповідно - метою нашої роботи стало дослідити геометричні властивості стегнової кістки щурів при експериментальній інтоксикації фумонізинами. Досліджувані характеристики включали вимірювання кісткової денситометрії та остеометричних параметрів, аналіз вмісту мікроелементів, комплексний аналіз механічних характеристик кісткового поперечного перерізу середнього діафіза, оцінку кристалічності мінеральної фази.

\section{Матеріал і методи досліджень}

Всі експериментальні процедури були затверджені Комітетом місцевої біоетики в Державному науководослідному контрольному інституті (ДНДКІ) ветеринарних препаратів та кормових добавок та виконані 
відповідно до Директиви 2010/63/СС Європейського Парламенту та Ради щодо захисту тварин, які використовуються для наукових цілей. Дослідження проводили в умовах віварію ДНДКІ ветеринарних препаратів та кормових добавок.

Для дослідження було відібрано 40 щурів-самців (5-тижневого віку) лінії Вістар. Після індивідуального зважування тварин поміщали окремо в поліпропіленові клітки (розміри $380 \times 200 \times 590$ мм) і залишали для акліматизації до нових лабораторних умов на тиждень. Щурів утримували в приміщенні за температури $21 \pm 3{ }^{\circ} \mathrm{C}$ та вологості $55 \pm 5 \%$. Тварини мали вільний доступ до води протягом 12 год/12 год циклу день/ніч. Після періоду акліматизації тварини були випадковим шляхом розподілені у дві групи: не інтоксиковану фумонізинами контрольну групу (група К; $\mathrm{n}=20$ ) та інтоксиковану фумонізинами групу (група $\mathrm{FB} ; \mathrm{n}=20$ ). Щурі обох груп споживали збалансований корм для гризунів, з метою забезпечення всіх харчових потреб тварин, зазначених у директиві AIN-93M (Reeves et al., 1993). Цей корм також було попередньо досліджено на вміст FB.

Фумонізинотоксикоз був викликаний щоденним введенням сумарного фумонізину (FB B1 + FB B2) внутрішньошлунково в дозі 90 мг/кг маси тіла на кожну тварину в групі FB протягом 21 доби. Оскільки немає даних літератури і летальна доза $\mathrm{DL}_{50} \mathrm{FB}$ для щурів невідома (McKean et al., 2006), нами в попередніх дослідженнях були встановлені дози $\mathrm{DL}_{50}$ (900 мг/кг маси тіла). Виходячи 3 наших попередніх результатів, введена доза FВ В1+ FВ В2 (75\% і 25\% відповідно, підтверджена методом HPLC-MC, рівна $1 / 10$ встановленого значення $\mathrm{DL}_{50}$, була достатньою для отримання клінічних ознак у всіх інтоксикованих тварин у цьому дослідженні. На 21-у добу експерименту усіх щурів зважували, по 6 голів $з$ кожної групи за допомогою інгаляції $\mathrm{CO}_{2}$ піддавалися евтаназії.

Для досліджень вирізали, відбирали та зважували обидві стегнові кістки, які були розсічені, відпрепаровані і після індивідуальних вимірювань ваги і довжини кістки були загорнуті в марлю, попередньо замочену в ізотонічному розчині натрію хлориду, та заморожені при мінус $25^{\circ} \mathrm{C}$ для подальших досліджень.

У подальших аналізах праву стегнову кістку піддавали випробуванням на міцність, а кістки, зібрані 3 лівого боку щурів, були призначені для геометричних вимірювань і денситометричних досліджень. Тест на вигин кісток середнього діафіза у 3-точковому вимірі виконували на універсальній випробувальній машині Zwick Z010 (Zwick GmbH \& Company KG, Ulm, Нiмeччина), оснащеній вимірювальною голівкою діапазону дії 10 кН і з'єднаних з комп'ютером TestXpert II 3.1 програмне забезпечення (Zwick GmbH \& Company $\mathrm{KG}$, Ulm, Німеччина). До аналізу кістка була розміщена горизонтально на двох округлих опорах. Відстань між опорами L встановлювали в кожному випадку на 40\% від загальної довжини кістки. Навантаження застосовувалося в передньо-задній (А-Р) площині кістки зі швидкістю переміщення 10 мм/хв до перелому (рис. 1). 3 отриманих наборів кривих були ви- значені такі структурні ознаки кісткової тканини: вихідне навантаження $\mathrm{F}_{\mathrm{el}}$, як максимальна сила при еластичній (оборотній) деформації кістки; еластична деформація $\mathrm{x}_{\mathrm{el}}$, як деформація кістки на межі текучості; граничне навантаження $\mathrm{F}_{\mathrm{m}}$, як сила, що викликає перелом кістки; деформація в точці руйнування $\mathrm{X}_{\mathrm{m}}$; жорсткість $\mathrm{S}$, як нахил початкової еластичної частини кривої навантаження (зміщення), що відображає стійкість кістки до деформації; еластична енергія $\mathrm{W}_{\mathrm{el}}$, як енергія, що проявляється кісткою і працює до перелому, $\mathrm{W}_{\max }$, як загальна робота, виконана для розлому кістки. Всі властивості визначали за допомогою програмного забезпечення Origin 2016 (OriginLab, Northampton, MA).

Розрахунок $i$ визначення геометричних властивостей кістки. Для розрахунку поперечних перерізів кістки вимірювали горизонтальні (M-L площини) зовнішні Н i внутрішні h, а також вертикальні (площину A-P) зовнішні В і внутрішні діаметри b поперечного перерізу середини діафіза. На підставі цих вимірювань були розраховані такі геометричні властивості: середня відносна товщина стінок (MRWT), площа поперечного перерізу кортикальної зони А i кортикальний індекс CI (Ferretti et al., 2003). Оскільки під час аналізу міцності кістка завантажувалася в площину А-P, розраховувався другий (поперечний) момент інерції $\mathrm{I}_{\mathrm{x}} \mathrm{i}$ радіус обертання $\mathrm{R}_{\mathrm{g}}$, середньолатеральної (M-L) осі. Другий момент інерції $\mathrm{I}_{\mathrm{x}}$ не $\epsilon$ прямою геометричною ознакою кістки, але є критичною властивістю з точки зору оцінки жорсткості при вигині кістки. Він задається таким рівнянням:

$$
I_{x}=\frac{\pi}{64}\left(H \cdot B^{3}-h \cdot b^{3}\right)
$$

Аналогічно - радіус обертання $\mathrm{R}$ g обчислювали так:

$$
R_{g}=\sqrt{\frac{I_{x}}{A}}
$$

$\mathrm{R}_{\mathrm{g}}$ відображає теоретичну відстань, на якій повинна бути розташована вся площа ділянки, зосереджена в кільці цієї відстані від осі, щоб дати значення $\mathrm{I}_{\mathrm{x}}$, що дорівнює дійсній $\mathrm{I}_{\mathrm{x}}$ кістки поруч із заданою віссю. Також визначали товщину вертикальної стінки $\mathrm{WT}_{\mathrm{v}} \mathrm{i}$ вертикальний кортикальний індекс $\mathrm{CI}_{\mathrm{v}}$.

На підставі виміряних геометричних $\left(\mathrm{I}_{\mathrm{x}}, \mathrm{B}, \mathrm{L}\right)$ та структурних ознак $\left(\mathrm{F}_{\mathrm{el}}, \mathrm{F}_{\max }, \mathrm{x}_{\mathrm{el}}, \mathrm{x}_{\mathrm{m}}, \mathrm{S}\right)$ розраховано властивості матеріалу середнього діафізарного фрагмента кістки. Ці ознаки характеризують специфічні механічні властивості кортикальної тканини середнього вала і не залежать від розміру кістки та умов, за яких проводилися випробування на міцність. Модуль Юнга пружності Е представляє опір вигину кістки:

$$
E=\frac{S \cdot L^{3}}{48 \cdot I_{x}}
$$

Згинальний момент М може бути визначеним як навантаження з урахуванням відстані опори L та до довжини довжини кістки. Це вказує на властивість пружного навантаження кістки і розраховується за рівнянням: 


$$
M=\frac{F_{e l} \cdot L}{4}
$$

Вихід деформації $\varepsilon_{\mathrm{y}}$ i граничної деформації $\varepsilon_{\mathrm{f}}$ характеризують відносну деформацію. Значення $\varepsilon_{\mathrm{y}}$ вказує на максимальну деформацію кістки, здатної витримувати оборотну деформацію, тоді як кінцева деформація $\varepsilon_{\mathrm{f}}$ окреслює значення при переломі (Ferretti et al., 2003). Вони можуть бути розраховані із співвідношення:

$$
\varepsilon=\frac{6 \cdot x \cdot B}{L^{2}}
$$
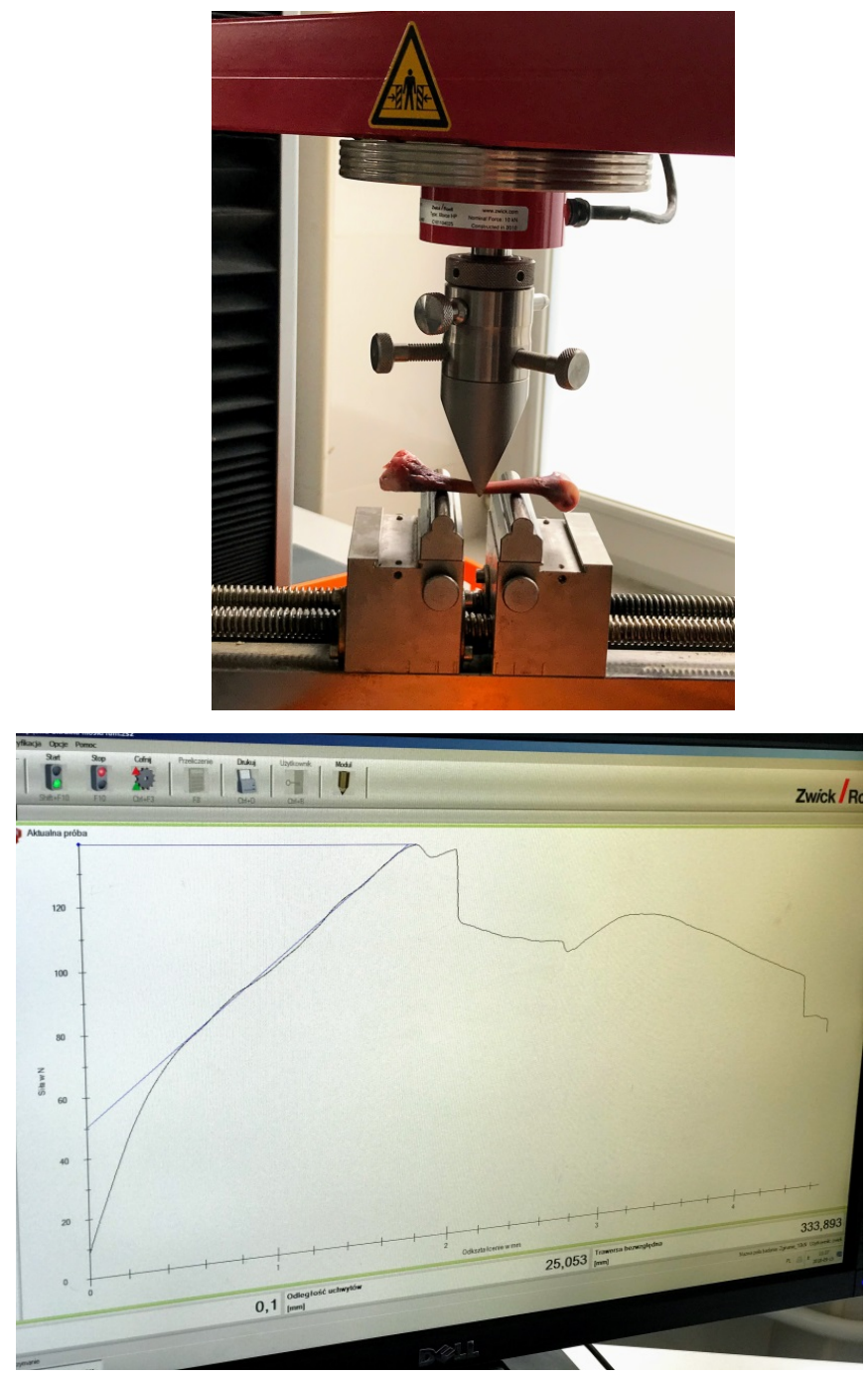

Рис. 1. Тест на визначення механічних, структурних та матеріальних властивостей кісток на основі 3-точкового випробування на згин, виконаного на універсальній випробувальній машині Zwick Z010 (Zwick-Roell GmbH \& Company KG, Ulm, Німеччина)

Вимірювання мінеральної щільності. Вимірювання мінеральної щільності кісткової тканини (BMD) i вмісту кісткового мінералу (BMC) проводили як для всієї кістки (загально), так і окремо для проксимальних $\left(\mathrm{BM}_{\mathrm{p}}\right.$ i $\mathrm{BMC}_{\mathrm{p}}$ відповідно), дистальних $\left(\mathrm{BMD}_{\mathrm{d}} \mathrm{i}\right.$ $\mathrm{BMC}_{\mathrm{d}}$, відповідно) і діафізарних $\left(\mathrm{BMD}_{\mathrm{m}}\right.$ i $\mathrm{BMC}_{\mathrm{m}}$, відповідно) частин, що охоплювали фрагмент кістки i піддавалися силовим випробуванням. Кістки сканува- де: $\mathrm{x}$ дорівнює $\mathrm{x}_{\mathrm{el}} \mathrm{i} \mathrm{x}_{\mathrm{m}}$ - вихід $\mathrm{i}$ кінцева деформація, відповідно. Пружне напруження $\sigma_{y}$ і граничне напруження $\sigma_{\mathrm{f}}$ були розраховані за формулою:

$$
\sigma=\frac{F \cdot B \cdot L}{8 \cdot I_{x}}
$$

де: $\mathrm{F}$ дорівнює $\mathrm{F}_{\mathrm{el}}$ i $\mathrm{F}_{\max }$ для пружної і кінцевої напруги відповідно. Пружне напруження $\sigma_{\mathrm{y}}$ відображає пружну міцність кортикальної кістки, граничне напруження $\sigma_{\mathrm{f}}$ дорівнює максимальній напрузі, яку кістка може витримати при вигині перед переломом.
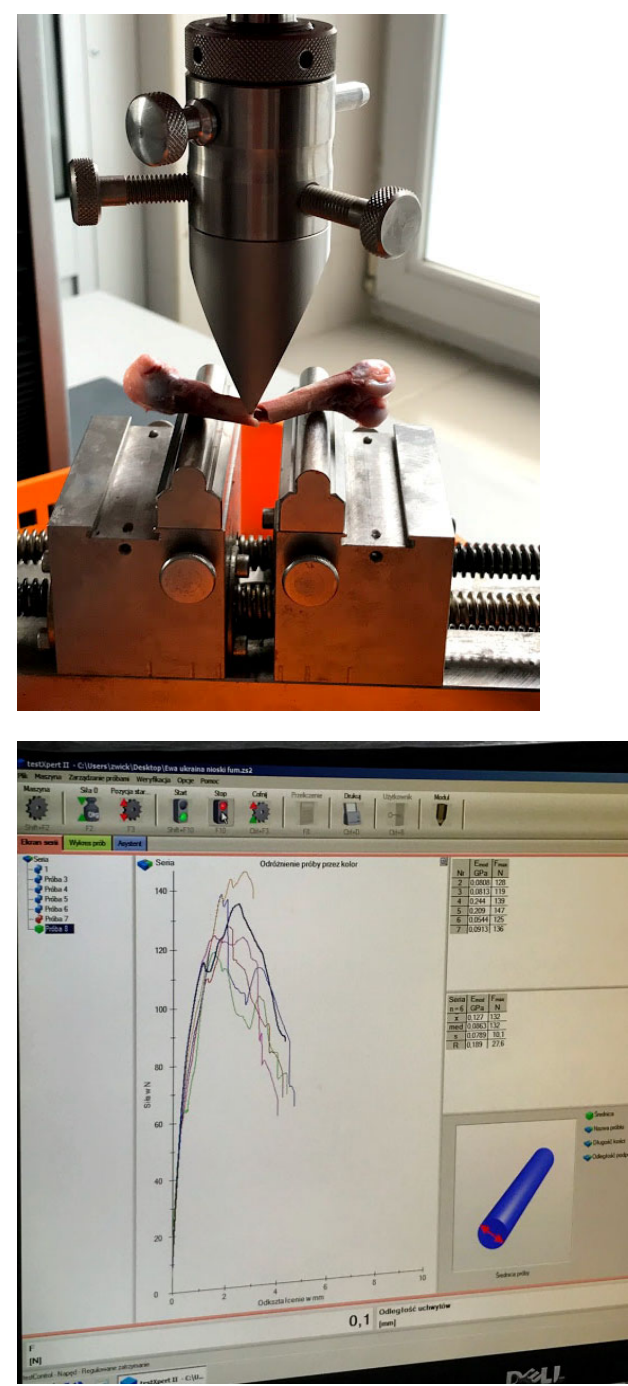

, використовуючи при цьому подвійну енергію поглинання рентгенівських променів Norland XR 43 (DEXA) з допомогою системи (Norland, Fort Atkinson, WI). Аналіз сканованих даних проводили 3 використанням визначених і окреслених оператором областей. Всі вимірювання проводилися одним і тим же оператором (рис. 2). 

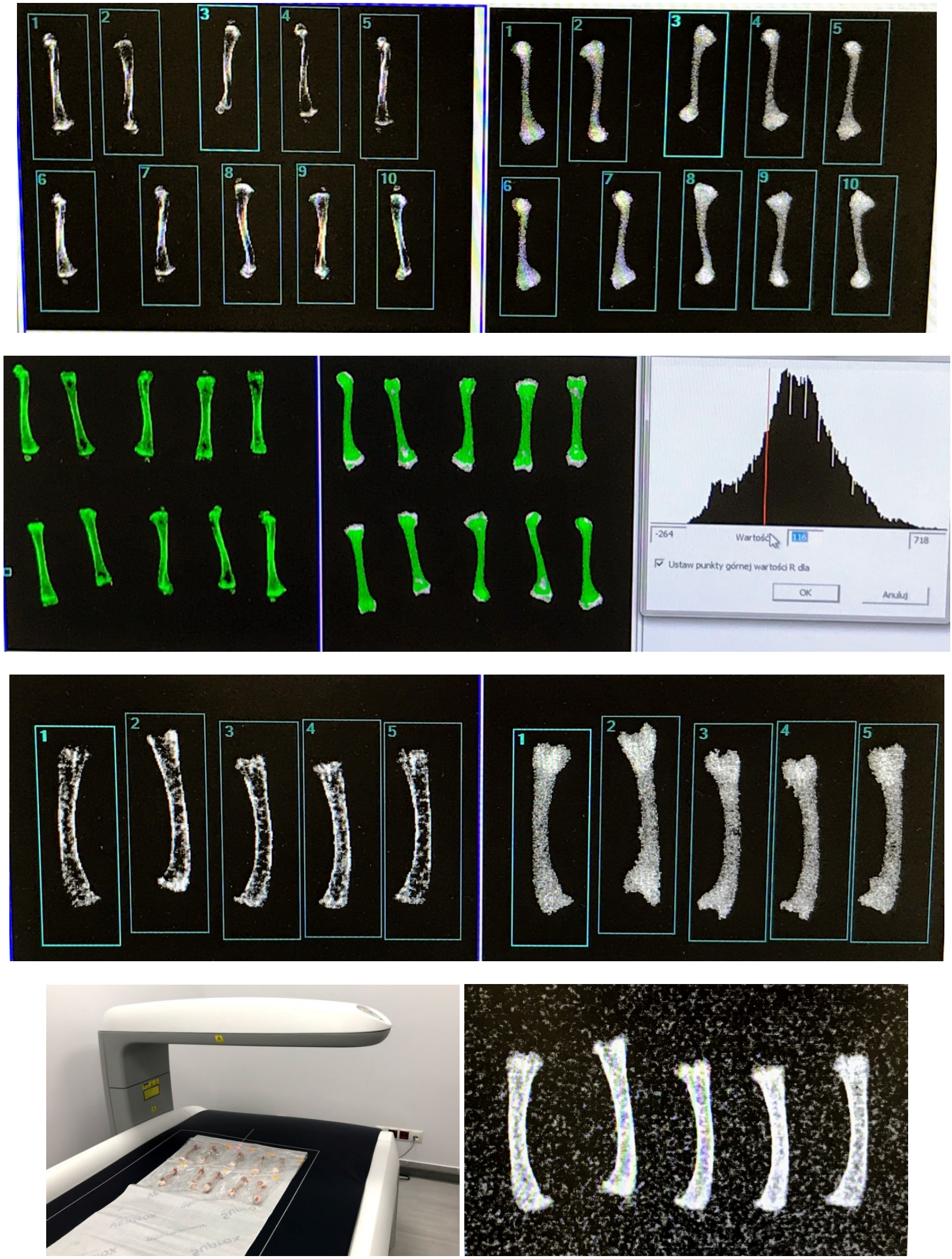

Рис. 2. Вимірювання мінеральної щільності кісткової тканини (BMD) і вмісту кісткового мінералу (BMC) методом денситометрії, проводили як для всієї кістки (загально), так і окремо для проксимальних $\left(\mathrm{BM}_{\mathrm{p}} \mathrm{i}\right.$ $\mathrm{BMC}_{\mathrm{p}}$ відповідно) і дистальних $\left(\mathrm{BMD}_{\mathrm{d}}\right.$ i $\mathrm{BMC}_{\mathrm{d}}$, відповідно) частин

Вимірювання щільності кісткової тканини (або щільності матеріалу) BTD, проводили 3 допомогою гелієвого газового пікнометра АсcuРус 1330
(Micromeritics, Inc., Norcross, GA), оснащеного $10 \mathrm{~cm}^{3}$ металевим вимірювальним циліндром. При цьому визначали довжину середньої діафізарної частини 
$\left(\mathrm{BTD}_{\mathrm{m}}\right)$ та довжину проксимальних $\mathrm{i}$ дистальних $\left(\mathrm{BTD}_{\mathrm{p}}\right.$ i $\mathrm{BTD}_{\mathrm{d}}$, відповідно) відділів кістки. Спочатку зразки нагрівали в печі при $105^{\circ} \mathrm{C}$ протягом 24 год для видалення зв’язаної води і потім охолоджували до кімнатної температури у вакуумних ексикаторах. Зневоднені маси зразків вимірювали 3 точністю до 0,0001 г і визначали в режимі аналізу перед вимірюванням, пізніше об'єм вимірювали до $0,0001 \mathrm{~cm}^{3}$ (Tomaszewska et al., 2015).

Після оцінки денситометричних властивостей кістки їх мінералізували в муфельній печі при $600{ }^{\circ} \mathrm{C}$ для визначення відсотка золи кістки. Відсоток золи визначали відносно вологої кісткової маси. Вміст Са в кістках визначали за допомогою індуктивно-зв'язаної плазмової атомно-емісійної спектрометрії з використанням спектрометра PS 950 (Leeman Labs, New Hampshire), (PN-ISO 6869, 2002). Загальний вміст P у зразках визначали спектрофотометрично (PN-ISO $6491,2000)$ за допомогою колориметричного методу 3 альфа-апаратом Helios (Unicam Instruments, Cambridge, UK). Дані аналізували за допомогою програмного забезпечення Statistica 12 (StatSoft, Inc., Tulsa, OK).

\section{Результати та їх обговорення}

Нами встановлено, що токсичні дози FB не впливали на масу тіла тварин. Протягом дослідження суттєвих відхилень між контрольною та дослідними групами не виявляли. До початку досліджень контрольна та FB-інтоксикована група щурів важили $121,9 \pm 2,7$ г та $123,1 \pm 3,7$ г відповідно. Контрольна група щурів показала незначне зменшення маси тіла на початку експерименту, але в кінці експерименту показник маси тіла становив $235,0 \pm 1,7$ г, тимчасом як FBінтоксикована група важила майже $219,1 \pm 2,7$ г (табл. 1).

Таблиця 3

Геометричні властивості середини діафізарної частини стегнової кістки, отриманої від контрольних і FBінтоксикованих щурів $(\mathrm{M} \pm \mathrm{m}, \mathrm{n}=6)$

\begin{tabular}{|c|c|c|}
\hline \multirow{2}{*}{ Геометричні властивості } & \multicolumn{2}{|c|}{ Групи } \\
\hline & контроль & фумонізин \\
\hline А-Р плоский зовнішній діаметр В, мм & $2,54 \pm 0,08$ & $2,61 \pm 0,09$ \\
\hline А-Р площині внутрішнього діаметра b, мм & $1,35 \pm 0,11$ & $1,59 \pm 0,06^{* * *}$ \\
\hline Зовнішній діаметр M-L (H), мм & $3,35 \pm 0,21$ & $3,49 \pm 0,21$ \\
\hline Внутрішній діаметр M-L (h), мм & $1,83 \pm 0,09$ & $1,96 \pm 0,07^{*}$ \\
\hline Площа поперечного перерізу А, мм² & $4,71 \pm 0,23$ & $4,69 \pm 0,30$ \\
\hline Середня відносна товщина стінки MRWT, - & $0,92 \pm 0,11$ & $0,76 \pm 0,09 *$ \\
\hline Кортикальний індекс CI,\% & $46,3 \pm 7,5$ & $41,6 \pm 6,9$ \\
\hline Вертикальний кортикальний індекс $\mathrm{CI}_{\mathrm{V}}$, \% & $46,9 \pm 6,2$ & $39,1 \pm 5,6^{*}$ \\
\hline Момент інерції поперечного перерізу $\mathrm{I}_{\mathrm{x}}$, мм $^{4}$ & $2,46 \pm 0,62$ & $2,63 \pm 0,23$ \\
\hline Радіус обертання $R_{g}$, мм & $0,72 \pm 0,06$ & $0,75 \pm 0,04$ \\
\hline
\end{tabular}

Примітки: * $\mathrm{P}<0,05 ; * * \mathrm{P}<0,01 ; * * * \mathrm{P}<0,001$

Площина A-P - передньо-задня (вертикальна) площина; Площина M-L - медіально-латеральна (горизонтальна) площина.

\section{Таблиця 1}

Динаміка зміни маси тіла контрольних і FBінтоксикованих щурів

\begin{tabular}{lcc}
\hline \multirow{2}{*}{ Показники } & \multicolumn{2}{c}{ Групи } \\
\cline { 2 - 3 } & контроль & фумонізин \\
\hline Початкова маса тіла, г & $121,9 \pm 2,7$ & $123,1 \pm 3,7$ \\
Маса тіла наприкінці, г & $235,0 \pm 1,7$ & $219,1 \pm 2,7$ \\
Загибель тварин & відсутня & відсутня \\
\hline
\end{tabular}

Як видно з даних таблиці 1, маса тіла тварин FBінтоксикованої групи в кінці ексеперементу була нижчою на 6,8\%, порівняно 3 контрольною групою. Проте змінювалася вага внутрішніх органів, так FBінтоксикованих щурів маса внутрішніх органів збільшувався порівняно 3 органами контрольних щурів (табл. 2).

\section{Таблиця 2}

Коефіцієнти маси внутрішніх органів, отримані від контрольних і FB-інтоксикованих щурів $(\mathrm{M} \pm \mathrm{m}, \mathrm{n}=6)$

\begin{tabular}{|c|c|c|}
\hline \multirow{2}{*}{ Органи } & \multicolumn{2}{|c|}{ Групи } \\
\hline & контроль & фумонізин \\
\hline Печінка & $33,9 \pm 0,2$ & $39,7 \pm 1,3 *$ \\
\hline Легені & $5,3 \pm 0,3$ & $9,3 \pm 2,1^{*}$ \\
\hline Серце & $4,1 \pm 1,3$ & $3,5 \pm 0,1^{*}$ \\
\hline Нирка ліва & $2,7 \pm 0,1$ & $3,3 \pm 0,2 *$ \\
\hline Нирка права & $2,5 \pm 0,0$ & $3,2 \pm 0,3^{*}$ \\
\hline Селезінка & $4,2 \pm 0,4$ & $5,2 \pm 0,5^{* *}$ \\
\hline
\end{tabular}

Введення дослідним тваринам FB не впливало на вагу стегнової кістки, хоча зменшувало ііі довжину порівняно 3 контрольною групою. Так, довжина стегнової кістки контрольної і дослідної групи становила $32,5 \pm 1,2$ та 30,6 \pm 0,6, відповідно стегнові кістки FBінтоксикованих щурі були коротші на 5,8\%.

Значення мінеральної щільності кісток та щільності кісткової тканини між групами не відрізнялися, але у FB-інтоксикованих щурів спостерігалося зниження вмісту кісткового мінералу ВМС і відсотка кісткової золи. Однак після інтоксикації FВ значення обох внутрішніх діаметрів зросли (табл. 3).

Площина А-Р - передньо-задня (вертикальна) площина; Плоцина М-L- медіально-латеральна (горизонтальна) площина. 
Як результат, середня товщина стінок вертикального кортикального індексу зменшувалась. Серед структурних властивостей середньої діафізарної частини стегнової кістки максимальна сила пружності за навантаження, гранична сила, пружна енергія та робота руйнування значно знизилися у FBінтоксикованих щурів (табл. 4), а значення всіх визначених фізичних параметрів матеріалу, окрім деформації, зменшилися у тварин цієї групи (табл. 5).

\section{Таблиця 4}

Структурні властивості середньої діафізарної частини стегнової кістки, отриманої від контрольних і FBінтоксикованих щурів $(\mathrm{M} \pm \mathrm{m}, \mathrm{n}=6)$

\begin{tabular}{|c|c|c|}
\hline \multirow{2}{*}{ Структурні властивості } & \multicolumn{2}{|c|}{ Групи } \\
\hline & контроль & фумонізин \\
\hline $\begin{array}{l}\text { Максимальна сила } \\
\text { пружності } \mathrm{F}_{\mathrm{el}}, \mathrm{H}\end{array}$ & $73 \pm 10$ & $51 \pm 6^{* * *}$ \\
\hline Гранична сила $\mathrm{F}_{\max }, \mathrm{H}$ & $112 \pm 9$ & $100 \pm 15$ \\
\hline Пружна енергія $\mathrm{W}_{\mathrm{el}}$, мДж & $9,09 \pm 2,91$ & $5,43 \pm 0,94^{*}$ \\
\hline $\begin{array}{l}\text { Робота руйнування } \mathrm{W}_{\max } \text {, } \\
\text { мДж }\end{array}$ & $47,6 \pm 5,3$ & $37,2 \pm 8,0^{*}$ \\
\hline Твердість S, H/мм & $284 \pm 55$ & $255 \pm 44$ \\
\hline
\end{tabular}

\section{Таблиця 5}

Властивості матеріалу стегнової кістки, отримані від контрольних і FB-інтоксикованих щурів $(\mathrm{M} \pm \mathrm{m}, \mathrm{n}=6)$

\begin{tabular}{lcc}
\hline \multirow{2}{*}{ Властивості матеріалу } & \multicolumn{2}{c}{ Групи } \\
\cline { 2 - 3 } & контроль & фумонізин \\
\hline Модуль Юнга пружності, ГПа & $4,92 \pm 1,02$ & $3,39 \pm 0,67^{*}$ \\
Гранична деформація,\% & $5,44 \pm 0,94$ & $6,66 \pm 0,96 *$ \\
Згинальний момент, Н-m & $0,22 \pm 0,06$ & $0,15 \pm 0,02^{*}$ \\
Напруга виходу, МПа & $115 \pm 32$ & $74 \pm 13^{*}$ \\
Граничне напруга, МПа & $186 \pm 26$ & $158 \pm 11^{*}$ \\
\hline Примітки: * $\mathrm{P}<0,05 ; * * \mathrm{P}<0,01 ; * * * \mathrm{P}<0,001$
\end{tabular}

Нами проведено тест на 3-точковий згин, який показав, що кістки у групі щурів FB характеризувалися зниженою механічною витривалістю і більш "гумоподібною" (нееластичною) природою. Кістки щурів групи FB були значно менш жорсткими і схильними до пластичних деформацій, про що свідчать результати: зниження величини сили пружності, граничної сили та пружної енергії. На нашу думку, це було результатом змін геометрії кістки, оскільки кістки групи щурів FB характеризувалися зменшеною довжиною i зміненим просторовим розподілом кортикальної кісткової тканини (що відбулося внаслідок зменшення розмірів внутрішніх діаметрів), середньою товщиною стінок і вертикальним кортикальним індексом, що вказує на більш медулярну порожнину кіски. Крім того, аналіз властивостей матеріалу показав, що в той час, як кістки обох груп щурів руйнувалися під однаковим навантаженням, кістки з групи щурів FB зазнавали швидших змін, на що вказує значно більші значення кінцевої деформації, і характеризувалися підвищеним ризиком перелому, як наслідок зниження енергопоглинаючої здатності всієї кістки (робота від руйнування). Знижена механічна витривалість приз- вела безпосередньо до змін у просторовому розподілі маси кістки, оскільки поріг пластичності та межа міцності, які характеризують навантаження геометрії кісток, були значно нижчими у групі FBінтоксикованих щурів.

Однак схильність кістки до швидкої деформації і руйнування під дією зовнішніх сил може бути також підсилена й іншими факторами, такими як зміни в мінералізації або будові органічної фази. В наших дослідженнях як кількісні (мінеральний склад кістки, відсоток золи), так і якісні (мінеральний склад) показники кісткової мінералізації за впливу FB, негативно впливали на кістки.

Зміни у складі матеріалу кісткової тканини підтверджувалися змінами мінерального складу сироватки крові. Так, концентрація Са в сироватці контрольних щурів досягла значення 2,55 $\pm 0,11$ ммоль/л і суттєво відрізнялася від значення FB-інтоксикованої групи $(2,21 \pm 0,20$ ммоль/л; $\mathrm{P}<0,05)$. Вміст $\mathrm{P}$ у сироватці крові щурів був значно нижчим у групі $\mathrm{FB}$ порівняно 3 контрольною групою $(\mathrm{P}<0,001)$ і становив $2,08 \pm$ 0,23 ммоль/л і 3,22 \pm 0,56 ммоль/л, відповідно. Тобто вміст Са та $\mathrm{P}$ в сироватці крові FB-інтоксикованих щурів був нижчим на $13,4 \%$ та $35 \%$, відповідно, ніж у тварин контрольної групи. Значних змін зазнавав мінеральний склад кісток. Вміст $\mathrm{Ca}, \mathrm{Cu}, \mathrm{Fe}, \mathrm{Mn}, \mathrm{Sr}$ та $\mathrm{Zn}$ у кістці значно знижувався у FB-інтоксикованих щурів порівняно $з$ контрольною групою (рис. 3).

Інтоксикація $\mathrm{FB}$ не впливала на вміст $\mathrm{Ba}, \mathrm{Cd}, \mathrm{Cr}$, $\mathrm{Mg}, \mathrm{Mo}, \mathrm{P}, \mathrm{PB}$ i S (рис. 3). Однак співвідношення $\mathrm{Ca} / \mathrm{P}$ було зменшено. Інтоксикація $\mathrm{FB}$ призвела до зниження сироваткових концентрацій Са і Р і зниження мінерального складу кісток, що було доведено і встановлено як за денситометрією, так і за допомогою аналізу ICP-OES.

Ми прагнули дослідити, чи може інтоксикація FB змінювати структуру гідроксиапатиту в кістках. Нанокристали гідроксиапатиту мають форму пластинок довжиною 40-60 нм, шириною 20-30 нм і товщиною 1,5-5 нм та орієнтовані паралельно осі колагенової фібрили. Нанокристали гідроксиапатиту володіють двома найважливішими для фізіології кісткової тканини властивостями: перебувають в динамічній рівновазі з біологічним оточенням в циклі ремоделювання (резорбції/мінералізаціі) i виявляють високий рівень механічних властивостей. Нанокристалічний гідроксиапатит має підвищену здатність адсорбувати білки, необхідні для життєдіяльності клітин, володіє вибірковістю по відношенню до функцій клітин, що утворюють кісткову i фіброзну тканини. Сімдесят відсотків кістки складаються з неорганічного мінерального гідроксиапатиту, який є переважно кристалічним, хоча може бути в аморфних формах. Механізми заміщення, що відбуваються в гідроксиапатиті кістки, включають міжкристалічний обмін і рекристалізацію внаслідок розчинення і риформінгу нанокристалів 3 додаванням нових іонів до кристалічної структури, що замінюють $\mathrm{Ca}^{2+}$ або адсорбуються на поверхні нанокристалів, що відмічалося змінами у групі тварин 3 FB. 

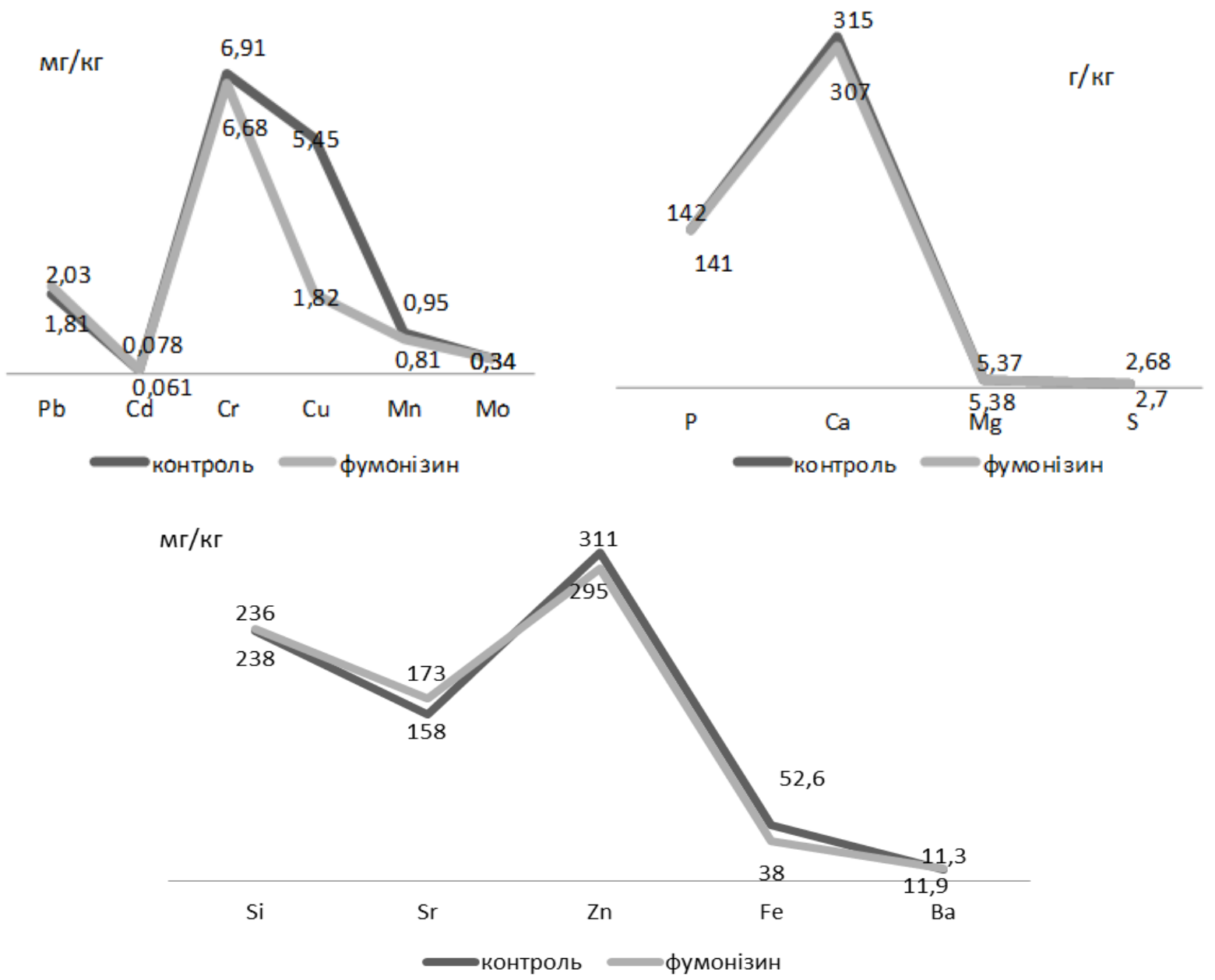

Рис. 3. Макро- і мікроелементи в кістковій тканині, отримані від контрольних і FB-інтоксикованих щурів

Середній розмір нанокристалів гідроксиапатиту апатитової кістки, як в площині a-b, так і по осі z зменшувався у FB-інтоксикованих щурів (рис. 4).

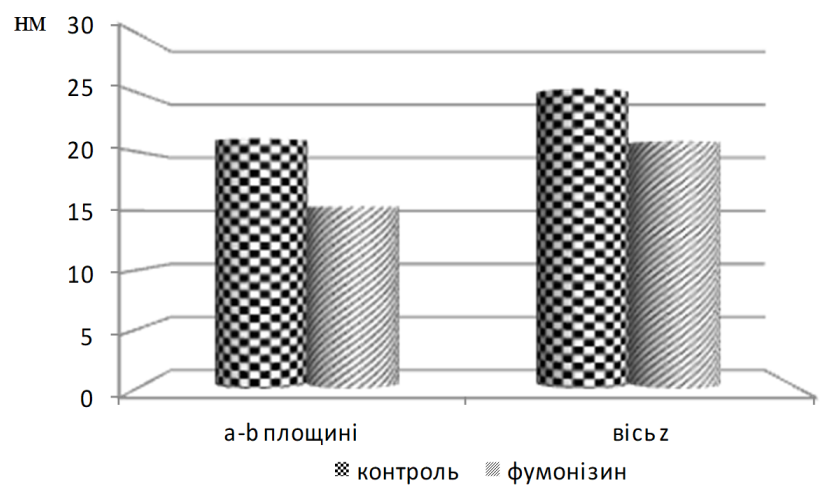

Рис. 4. Розмір нанокристалів гідроксиапатиту в стегновій кістці, отриманий від контрольних і FBінтоксикованих щурів

Як показали XRD аналізи, в нашому дослідженні спостерігалися відмінності в розмірах нанокристалів гідроксиапатиту, так менші нанокристали були виявлені у групі FB-інтоксикованих щурів. Зазвичай, більші кристали мають тенденцію до зниження жорсткості кістки, в той час як надто малі кристали не під- силюють композиційний матеріал кістки. Це спостерігалося в нашому дослідженні, оскільки група FB характеризувалася зниженою механічною витривалістю кісток, проте жорсткість була однією з небагатьох визначених механічних параметрів, які були однаковими в обох групах. Різниця в розмірі кристалітів гідроксиапатиту може бути ефектом іонного включення в кристалічну фазу кістки, оскільки ряд бівалентних катіонів, як $\mathrm{Fe}, \mathrm{Mn}, \mathrm{Mg}$ i $\mathrm{Sr}$, можуть замінити іони кальцію в кристалічних структурах гідроксиапатиту. Однак це можна тільки припустити, оскільки більшість елементів може бути розташована як в кістково-мінеральній, так і в органічній фазах, що унеможливлює віднесення їх до конкретного компонента кістки.

Нами встановлено, що одним $з$ наслідків дії $\mathrm{FB} \epsilon$ порушення мінерального гомеостазу, включаючи Кальцій і Фосфор. У нашому дослідженні виявлено негативний впливав FB на гомеостаз Са і Р, що було доведено зниженням їх концентрації у сироватці та зниженням вмісту Са у кістках. Крім того, аналіз ICPOES виявив порушення гомеостазу інших іонів, тісно пов'язаних із метаболізмом кісток $(\mathrm{Cu}, \mathrm{Fe}, \mathrm{Mn}, \mathrm{Zn})$ у групі FB. Сдиний мікроелемент, вміст якого збільшувався в групі $\mathrm{FB}$, був $\mathrm{Sr}$, він може замінити деякі іони 
Са в кістці, але ця заміна не підвищує структурної і матеріальної міцності кісток.

\section{Висновки}

За результатами проведеної роботи встановлено, що значення мінеральної щільності кісток і мінеральної щільності кісткової тканини не відрізнялися між групами тварин, але у групі FB-інтоксикованих щурів мінеральний вміст стегнової кістки і відсоток кісткової золи були нижчими, ніж у тварин контрольної групи. Детальний мінеральний аналіз кісток показав, що вміст у кістках $\mathrm{Ca}, \mathrm{Cu}, \mathrm{Fe}, \mathrm{Mn}, \mathrm{Sr}$ та $\mathrm{Zn}$ значно зменшувався у щурів інтоксикованих фумонізином порівняно $з$ показниками контрольної групи. Також були виявлені зміни у структурі кістково-мінеральної фази, відбувалося зменшення розміру нанокристалів гідроксиапатиту кістки.

Перспективи полягають у подальшому вивченні впливу фумонізинів на кісткову тканину новонародженого потомства щурів, матері котрих під час вагітності були інтоксиковані фумонізинами.

\section{References}

Álvarez-Lloret, P., Lind, P.M., Nyberg, I., Orberg, J., \& Rodríguez-Navarro, A.B. (2009). Effects of 3,3',4,4',5-pentachlorobiphenyl (PCB126) on vertebral bone mineralization and on thyroxin and vitamin $\mathrm{D}$ levels in Sprague-Dawley rats. Toxicol. Lett., 187(2), 63-68. doi: 10.1016/j.toxlet.2009.01.030.

Antonissen, G., Croubels, S., Pasmans, F., Ducatelle, R., Eeckhaut, V., Devreese, M., Verlinden, M., Haesebrouck, F., Eeckhout, M., De Saeger, S., Antlinger, B., Novak, B., Martel, A., \& Van Immerseel, F. (2015). Fumonisins affect the intestinal microbial homeostasis in broiler chickens, predisposing to necrotic enteritis. Vet. Res., 46, 98. doi: 10.1186/s13567-0150234-8.

EC (European Commission), (2006). Commission Recommendation No 576/2006 of 17 August 2006 on the presence of deoxynivalenol, zearalenone, ochratoxin A, T-2 and HT-2 and fumonisins in products intended for animal feeding. Off. J. Eur. Union, L229: 7.

EC (European Commission), (2016). Commission Recommendation No 2016/1219 of 29 July 2016 amending Recommendation 2006/576/EC as regards deoxynivalenol, zearalenone and ochratoxin A in pet food. Off. J. Eur. Union, L208: 59.FDA (Food and Drug Administration), (2001). Guidance for Industry: Fumonisin levels in human foods and animal feeds. Federal Register, 66(208), 56688-56689.

Ferretti, J.L., Cointry, G.R., Capozza, R.F., \& Frost, H.M. (2003). Bone mass, bone strength, muscle-bone interactions, osteopenias and osteoporoses. Mech. Ageing Dev., 124(3), 269-279. https://www.ncbi.nlm.nih.gov/ pubmed/12663124.

Gelderblom, W.C.A., Snyman, S.D., Lebepe-Mazur, S., Smuts, C.M., Van Der Westhuizen, L., Marasas, W.F.O., Victor, T.C., Knasmueller, S., \& Huber, W.
(1996). Hepatotoxicity and carcinogenicity of the fumonisins in rats. Adv. Exp. Med. Biol., 392, 279296. https://link.springer.com/chapter/10.1007/978-14899-1379-1_24.

Hodgson, S., Thomas, L., Fattore, E., Lind, P.M., Alfven, T., Hellström, L., Håkansson, H., Carubelli, G., Fanelli, R., \& Jarup, L. (2008). Bone mineral density changes in relation to environmental PCB exposure. Environ. Health Persp., 116, 1162-1166. doi: 10.1289/ehp.11107.

Kotsyumbas, 1., Brezvyn, O., Rudyk, G., Guta, Z., \& Gutyj, B. (2016). Effect of fumonisin toxicosis on rats. Pasze przemysłowe. Lublin, 3/4, 108-115.

Ledoux, D.R., Brown, T.P., Weibking, T.S., \& Rottinghaus, G.E. (1992). Fumonisin toxicity in broiler chicks. J. Vet. Diagn. Invest., 4, 330-333. doi: 10.1177/104063879200400317.

McKean, C., Tang, L., Tang, M., Billam, M., Wang, Z., Theodorakis, C.W., Kendall, R.J., \& Wang, J.S. (2006). Comparative acute and combinative toxicity of aflatoxin B1 and fumonisin B1 in animals and human cells. Food Chem. Toxicol., 44, 868-876. doi: 10.1016/j.fet.2005.11.011.

Placinta, C.M., D’Mello, J.P.F., \& Macdonald, A.M.C. (1999). A review of worldwide contamination of cereal grains and animal feed with Fusarium mycotoxins. Anim. Feed Sci. Technol., 78(1-2), 21-37. doi: 10.1016/S0377-8401(98)00278-8.

Reeves, P.G., Nielsen, F.H., \& Fahey Jr., G.C. (1993). AIN-93 Purified diets for laboratory rodents: final report of the American Institute of Nutrition ad hoc writing committee on the reformulation of the AIN76A rodent diet. J. Nurt., 123, 1939-1951. doi: $10.1093 /$ jn/123.11.1939.

Riley, R.T., \& Voss, K.A. (2006). Differential sensitivity of rat kidney and liver to fumonisin toxicity: organspecific differences in toxin accumulation and sphingoid base metabolism. Toxicol. Sci., 92(1), 335-345. doi: 10.1093/toxsci/kfj198.

Rodríguez-Estival, J., Álvarez-Lloret, P., RodríguezNavarro, A.B., Mateo, R. (2013). Chronic effects of lead $(\mathrm{Pb})$ on bone properties in red deer and wild boar: relationship with vitamins and D3. Environ. Pollut., 174, 142-149. doi: 10.1016/j.envpol.2012.11.019.

Ross, P.F., Rice, L.G., Osweiler, G.D., \& Nelson, P.E. (1992). A review and update of animal toxicoses associated with fumonisin contaminated feeds and production of fumonisins by Fusarium isolates. Mycopathologia, 117(1-2), 109-114. https:/www.ncbi.nlm.nih. gov/pubmed/1513366.

Šegvić, M., \& Pepeljnjak, S. (2001). Fumonisins and their effects on animal health a brief review. Vet. Arhiv., 71, 299-323.

Tomaszewska, E., Dobrowolski, P., Kostro, K., Jakubczak, A., Taszkun, I., Jaworska-Adamu, J., Żmuda, A., Rycerz, K., Muszyński, S. (2015). The effect of HMB and 2-Ox administered during pregnancy on bone properties in primiparous and multiparous minks (Neivison vison). Bull.Vet. Inst. Pulawy, 59, 563-568. doi: 10.1515/bvip-2015-0084. 
Tomaszewska, E., Dobrowolski, P., Muszyński, S., Kostro, K., Taszkun, I., Żmuda, A., Blicharski, T., Hułas-Stasiak, M. (2017). DON-induced changes in bone homeostasis in mink dams. J. Vet. Res., 61(3), 357-362. doi: 10.1515/jvetres-2017-0047.

Tomaszewska, E., Dobrowolski, P., Winiarska-Mieczan, A., Kwiecień, M., Tomczyk, A., Muszyński, S., \& Radzki, R. (2016). Alteration in bone geometric and mechanical properties, histomorphometrical parameters of trabecular bone, articular cartilage, and growth plate in adolescent rats after chronic co-exposure to cadmium and lead in the case of supplementation with green, black, red and white tea. Environ. Toxicol. Pharmacol., 46, 36-44. doi: 10.1016/j.etap.2016.06.027.
Tomaszewska, E., Muszyński, S., Dobrowolski, P., Winiarska-Mieczan, A., Kwiecień, M., TomczykWarunek, A., Ejtel, M., Świetlicka, I., \& Gładyszewska, B. (2018). White tea is more effective in preservation of bone loss in adult rats co-exposed to lead and cadmium compared to black, red or green tea. Ann. Anim. Sci., In press. doi: 10.2478/aoas-20180026.

Voss, K.A., Chamberlain, W.J., Bacon, C.W., Herbert, R.A., Walters, D.D., \& Norred, W.P. (1995). Species chronic feeding study of the mycotoxin FB1 in B6C3F1 mice and Fischer 344 rats. Fundam. Appl. Toxicol., 24(1), 102-110. doi: 10.1093/toxsci/24.1.102. 